RESEARCH NOTE

\section{Wild Birds as Reservoir of Thermophilic Enteropathogenic Campylobacter Species in Southern Chile}

\section{H Fernández ${ }^{+}$, W Gesche*/*, A Montefusco*, R Schlatter**}

Instituto de Microbiología Clínica *Instituto de Salud Pública **Instituto de Zoología, Universidad Austral de Chile, Casilla Postal 567, Valdivia, Chile

Key words: Campylobacter - epidemiology reservoirs - wild birds

Thermophilic Campylobacter species (C. jejuni subsp. jejuni, $C$. coli and $C$. lari) are zoonotic bacteria worldwide recognized as important enteropathogens for human beings ( $\mathrm{P}$ Vandamme \& H Goosens 1992 Zbl Bakt 276: 447-452, H Fernández 1992 Ciên Cult 44: 39-43). A wide range of domestic and wild animal species, including mammals and birds, have been identified as natural reservoirs of Campylobacter in industrialized as well as in developing countries and, they could be a source of contamination for human beings, other animals, food and environmental water bodies (G Kapperud \& O Rosef 1983 Appl Environ Microbiol 45: 375-380, O Rosef et al. 1983 Appl Environ Microbiol 46: 855-859, M Blaser et al. 1983 Epidemiol Rev 5: 157-176, Fernández loc. cit.).

In the present study, wild birds from southern Chile were surveyed for fecal carriage of the classical thermophilic Campylobacter species in order to assess the regional wildlife reservoir of these bacteria.

Cloacal swabs were collected from a total of 392 adult wild-living birds representing seven species (Table). The birds were sampled in several

This work received financial support from Dirección de Investigación y Desarrollo, Universidad Austral de Chile, Grants S-92-05 and S-95-45 and FONDECYT Grants 59-89 and 1930353.

* In memoriam, deceased 27 May 1995

${ }^{+}$Corresponding author. Fax: +56-63-214475

Received 23 April 1996

Accepted 18 June 1996 places of the province of Valdivia $\left(39^{\circ} 28^{\prime}-40^{\circ} 20^{\prime}\right.$ southern latitude, $71^{\circ} 30^{\prime}-73^{\circ} 45^{\prime}$ western longitude) and the cloacal material collected was seeded into the transport-enrichment medium described by $\mathrm{H}$ Fernández (1992 Rev Microbiol São Paulo 23: 149-151) and transported to the laboratory. Following an enrichment period of $24 \mathrm{hr}$ at $42^{\circ} \mathrm{C}$ under microaerobic conditions in a GasPak system without the catalyst, cultivation was performed by plating each sample onto Skirrow agar. Plates were incubated for $48 \mathrm{hr}$ under the same conditions described above. Suspected colonies were identified morphologically (Gram stain), biochemically (oxidase, catalase, sensitivity to nalidixic acid and cephalotin, hippurate hydrolisis) and biotyped by Lior's scheme (1984 J Clin Microbiol 20: 636640).

The results obtained are shown in the Table. From the 392 birds studied, 95 (24.2\%) harbored thermophilic Campylobacter species being $C$. jejuni subsp. jejuni the most frequently isolated $(69.5 \%$ - 66/95) followed by C. coli $(23.1 \%-22 /$ 95). C. lari was isolated only from waterfowl (7.4\% - 7/95).

The frequency which Campylobacter was recovered from wild ducks $(67.4 \%)$ is higher than that reported by N Luechtefeld et al. (35\%) in northern Colorado (1980 J Cin Microbiol 12: 406-408) and similar to that reported by R Pacha et al. (73\%) in central Washington (1988 Can J Microbiol 34: 80-82). In those birds, as well as in seagulls and cormorants, we found the three classical thermophilic species of Campylobacter. From the two swans that were included in this study, one harbored $C$. jejuni subsp. jejuni and the second, $C$. lari. These results support previous findings (Luechtefeld et al. loc.cit., Pacha et al. loc. cit.) and suggest that waterfowl are natural reservoirs that could play a role in the waterborne spread of these bacteria. Waterborne outbreaks of Campylobacter-associated gastroenteritis involving aquatic birds as possible contamination source have been reported (SR Palmer et al. 1983 Lancet 1: 287-290, A Borczyc et al. 1987 Lancet 1: 164165).

The isolation rate of Campylobacter from pigeons and sparrows was higher than the one reported by S Matsusaki et al. in Japan (1985 3rd International Workshop on Campylobacter infection, Ottawa, Canada, Abstract $\mathrm{N}^{\mathrm{o}} 160$ ) but slightly lower than the one reported in 1988 by $\mathrm{H}$ Fernández (1988 Rev Inst Med Trop São Paulo 30: 357-360) for the same birds species from our geographical region. Pigeons and sparrows are birds that can live near human habitat and could be sources of contamination for water supplies and environment (Palmer loc.cit.). 
The lowest isolation rate was obtained from chimango caracara hawks (3.5\%), and as far as we know, this would be the first identification of members of the family Falconidae as reservoirs of thermophilic Campylobacter species.

Considering these results and previously published data (H Fernández et al. 1994 Rev Inst Med Trop São Paulo 36: 433-436), we can conclude that there exists an extensive indigenous reservoir of thermophilic Campylobacter in southern Chile. However, we do not know the contribution of each of these identified reservoirs to human infection. O Rosef et al. (1985 Appl Environ Microbiol 49: 1507-1510) and Y Weisman et al. (1986 Israel J Med Sci 22: 149) reported that wild birds carry Campylobacter serotypes that also occur in cases of human Campylobacter enteritis. Nevertheless, the potencial role of these birds in the epidemiology of human campylobacteriosis will require further studies involving antigenic, pathogenic and genotypic characterization of avian and human isolates.

\section{TABLE}

Isolation rates of thermophilic Campylobacter species and their biovars (Lior scheme) from different species of wild birds

\begin{tabular}{|c|c|c|c|c|c|c|c|c|c|}
\hline \multirow[t]{2}{*}{ Wild birds } & \multirow[t]{2}{*}{$\mathrm{N}$} & \multirow[t]{2}{*}{ Positive } & \multirow{2}{*}{$\begin{array}{c}\text { C. jejuni } \\
\text { biov } \\
\text { I }\end{array}$} & \multirow{2}{*}{$\begin{array}{c}\text { subsp. } \\
\text { biov } \\
\text { II }\end{array}$} & \multirow{2}{*}{$\begin{array}{c}\text { jejuni } \\
\text { biov } \\
\text { III }\end{array}$} & \multicolumn{2}{|c|}{ C. coli } & \multicolumn{2}{|c|}{ C. lari } \\
\hline & & & & & & $\begin{array}{l}\text { biov } \\
\text { I }\end{array}$ & $\begin{array}{l}\text { biov } \\
\text { II }\end{array}$ & $\begin{array}{l}\text { biov } \\
\text { I }\end{array}$ & $\begin{array}{l}\text { biov } \\
\text { II }\end{array}$ \\
\hline $\begin{array}{l}\text { Yellow-billed Pintail } \\
\text { Anas georgica }\end{array}$ & 46 & $31(76.4)$ & $6(19.3)$ & $8(25.8)$ & $2(6.4)$ & $7(22.6)$ & $5(16.1)$ & $2(6.4)$ & $1(3.2)$ \\
\hline $\begin{array}{l}\text { Kelp Gull } \\
\text { Larus dominicanus }\end{array}$ & 15 & $8(53.3)$ & $2(25.0)$ & $1(12.5)$ & $0(0)$ & $0(0)$ & $3(37.5)$ & $1(12.5)$ & $1(12.5)$ \\
\hline $\begin{array}{l}\text { Olivaceus Cormorant } \\
\text { Phalacrocorax olivaceus }\end{array}$ & 11 & $6(54.6)$ & $1(16.7)$ & $2(33.3)$ & $1(16.7)$ & $1(16.7)$ & $0(0)$ & $0(0)$ & $1(16.7)$ \\
\hline $\begin{array}{l}\text { Black-necked Swan } \\
\text { Cygnus melanocorypha }\end{array}$ & 2 & $2(100)$ & $0(0)$ & $1(50.0)$ & $0(0)$ & $0(0)$ & $0(0)$ & $0(0)$ & $1(50.0)$ \\
\hline $\begin{array}{l}\text { Feral Pigeon (intr.) } \\
\text { Columba livia }\end{array}$ & 104 & 11(10.6) & $3(27.3)$ & $4(36.4)$ & $0(0)$ & $1(9.1)$ & $3(27.3)$ & $0(0)$ & $0(0)$ \\
\hline $\begin{array}{l}\text { Chimango Caracara } \\
\text { Milvago chimango }\end{array}$ & 114 & $4(3.5)$ & $1(25.0)$ & $2(50.0)$ & $0(0)$ & $1(25.0)$ & $0(0)$ & $0(0)$ & $0(0)$ \\
\hline $\begin{array}{l}\text { European Sparrow (intr.) } \\
\text { Passer domesticus }\end{array}$ & 100 & $33(33.0)$ & $11(33.3)$ & $17(51.5)$ & $4(12.1)$ & $0(0)$ & $1(3.0)$ & $0(0)$ & $0(0)$ \\
\hline Total & 392 & $95(24.2)$ & $24(25.3)$ & $35(36.8)$ & $7(7.4)$ & $10(10.5)$ & $12(12.6)$ & $3(3.2)$ & $4(4.2)$ \\
\hline
\end{tabular}

$\mathrm{N}=$ number of birds studied; biov= biovar; $(\mathrm{l})=\%$. 